\title{
Kemitraan di Sektor Pelabuhan Dalam Mendukung Jasa Pelayanan di Pelabuhan (Analisis Pelaksanaan Kemitraan Di Pelabuhan Yos Sudarso Antara PT. Pelindo IV Cabang Ambon Dengan Pemerintah Kota Ambon)
}

\author{
Rizki Nurjannah Derlen ${ }^{1 *}$, Sumartono ${ }^{2}$, Hermawan ${ }^{3}$ \\ ${ }^{1}$ Jurusan Ilmu Administrasi Negara, Fakultas IImu Sosial, Universitas Darussalam \\ 2Jurusan IImu Administrasi Publik, Fakultas IImu Administrasi, Universitas Brawijaya \\ 3Jurusan Ilmu Administrasi Publik, Fakultas Ilmu Administrasi, Universitas Brawijaya
}

\begin{abstract}
Abstrak
Pelayanan publik yang berkualitas dalam sektor pelayanan jasa pelabuhan dihasilkan melalui kemitraan. Penelitian ini bertujuan untuk mendeskripsikan dan menganalisis bentuk kemitraan yang terjalin antara PT. Pelindo IV cabang Ambon dengan pemerintah kota Ambon, mendeskripsikan dan menganalisa pelaksanaan kemitraan serta menjelaskan faktor pendukung dan penghambat dalam penyelenggaraan kemitraan antara PT Pelindo IV cabang Ambon dengan pemerintah kota Ambon. Metode yang digunakan dalam penelitian ini adalah kualitatif. Bentuk kemitraan yang dibangun antara PT Pelindo IV cabang Ambon dengan pemerintah kota Ambon memiliki kecenderungan ke bentuk kerjasama consortia. Pihak-pihak yang terlibat dalam kemitraan ini adalah PT Pelindo IV cabang Ambon sebagai pemilik sumber daya modal, Pemerintah Kota Ambon sebagai pemilik sumber daya lahan, perusahaan pelayaran sebagai pengguna jasa lapangan penumpukan peti kemas yang dimitrakan dan masyarakat Kota Ambon sebagai konsumen dari barang yang didistribusikan melalui jasa pelayanan pelabuhan. Faktor pendukung kemitraan ini yaitu adanya arus bongkar muat barang yang dari tahun ke tahun mengalami peningkatan dan ketersediaan lahan. Faktor penghambat kemitraan ini yaitu masih belum selesainya proses pengkajian terhadap rencana relokasi pasar Nusaniwe, Belum adanya sosialisasi secara resmi dari Pemerintah Kota Ambon terkait relokasi pedagang pasar Nusaniwe, Masih diberlakukannya retribusi karcis di pasar Nusaniwe, Kurangnya koordinasi dan sinkronisasi antara Pemerintah Kota Ambon dengan PT Pelindo IV cabang Ambon sehingga rencana kemitraan ini menjadi terhambat.
\end{abstract}

Kata kunci : kemitraan, pelayanan jasa, sektor pelabuhan.

\section{Abstract}

The quality public service at port sector can be delivered through partnership. Research aims to describe and to analyze the form of partnership made between PT Pelindo IV of Ambon Branch and the Government of Ambon City, to describe and to analyze the implementation of this partnership, and to explain the factors supporting and constraining the implementation of partnership between PT Pelindo IV of Ambon Branch and the Government of Ambon City. Method of research is qualitative. The form of partnership developed between PT Pelindo IV of Ambon Branch and the Government of Ambon City is inclined toward the cooperation form of consortia. Any parties engaged within this partnership are PT Pelindo IV of Ambon Branch as the owner of capital resource, the Government of Ambon City as the owner of land resource, the shipping companies as the user of field service related to the arrangement of containers from partnership business, and the communities of Ambon City as the consumers for commodities distributed through port service. The factors that support partnership are the annual increase of load-discharge activities and the availability of land. Factors constraining the partnership are related to unfinished review for relocation plan of Nusaniwe Market, lack of official socialization from the Government of Ambon City about the relocation of Nusaniwe Market merchants, the prevail of ticket-based retribution at Nusaniwe Market, and lack of coordination and synchronization between the Government of Ambon City and PT Pelindo IV of Ambon Branch. All these constraining factors are truly impeding the partnership plan.

Keywords: partnership, service, port sector

\section{PENDAHULUAN}

Pelayanan publik merupakan cara untuk memenuhi kebutuhan baik barang maupun jasa.

Alamat Korespondensi Penulis: Rizki Nurjannah Derlen

Email : rizkinurjannahderlen@gmail.com

Alamat : Universitas Darussalam Jl. Tulehu Km 24 Kota Ambon kode pos : 97582
Dalam penyelenggaraan pelayanan publik, aparatur pemerintah bertanggung jawab untuk memberikan pelayanan yang terbaik kepada masyarakat demi menciptakan kesejahteraan Masyarakat dan terciptanya pemerintahan yang baik [1].

Demi terwujudnya pemerintahan yang baik melalui pelayanan, maka salah satu 
upayanya dapat dilakukan melalui program kemitraan. Al-wedyan mendefinisikan kemitraan sebagai jalinan kerjasama usaha yang dilakukan oleh pihak yang telah disepakati dengan prinsip saling menguntungkan dan saling membutuhkan karena pada dasarnya terdapat kekurangan dan kelebihan pada masing-masing pihak sehingga kerjasama itu diperlukan [2].

Sebagai Negara maritim transportasi laut menjadi salah satu alternatif yang dapat memudahkan masyarakat Indonesia untuk melakukan aktivitas berpindah tempat. Pemanfaatan laut sebagai sarana transportasi tentu saja memiliki berbagai kelebihan melihat Indonesia merupakan negara kepulauan.

Data PT Pelindo IV cabang Ambon pada tahun 2012 tentang arus kunjungan kapal, barang, dan penumpang melalui pelabuhan Ambon menunjukkan bahwa arus kunjungan kapal bermuatan barang dan peti kemas merupakan aktivitas terbesar dalam kurun waktu bulan januari sampai juli 2012 yaitu sekitar 420.840 ton. sementara jumlah aktivitas penumpang yang menggunakan jasa kapal yaitu sekitar 140.440 penumpang. Data tersebut menunjukkan bahwa peningkatan arus kunjungan kapal barang lebih tinggi dari arus kunjungan kapal penumpang.

Peningkatan arus kunjungan kapal dan barang yang semakin meningkat melebihi arus kunjungan penumpang menunjukkan bahwa pelabuhan dapat dikatakan sebagai tolok ukur dari tombak perekonomian karena merupakan sumber pemasukan yang strategis sebagai sumber pemasukan daerah. Namun, fakta dilapangan menunjukkan bahwa terbatasnya area lapangan penumpukan peti kemas yang dimiliki PT Pelindo IV cabang Ambon menyebabkan tidak maksimalnya pelayanan jasa di pelabuhan karena hal ini mengakibatkan keterlambatan dalam proses bongkar muat barang.

Demi tercapainya kelancaran aktivitas bongkar muat barang di pelabuhan Yos Sudarso, PT Pelindo IV cabang Ambon membangun kemitraan dengan Pemerintah Kota Ambon dalam upaya memanfaatkan pasar Nusaniwe yang merupakan aset Pemerintah Kota Ambon sebagai area perluasan lapangan penumpukan peti kemas.

Berangkat dari urgensitas kemitraan yang dilakukan untuk perluasan lapangan penumpukan peti kemas milik PT Pelindo IV cabang Ambon, peneliti merumuskan masalah dalam penelitian ini sebagai berikut : (1)
Bagaimanakah bentuk kemitraan antara PT. Pelindo IV cabang Ambon dengan pemerintah dalam pelayanan di pelabuhan Yos Sudarso Ambon? (2) Bagaimanakah pelaksanaan kemitraan antara PT. Pelindo IV cabang Ambon dengan pemerintah dalam pelayanan di pelabuhan Yos Sudarso Ambon? (3) Faktor-faktor apa sajakah yang mendukung dan menghambat proses kemitraaan antara PT. Pelindo IV cabang Ambon dengan pemerintah kota Ambon?.

Dengan mengacu pada latar belakang serta rumusan masalah yang telah disajikan, maka terlihat pada penelitian ini bertujuan untuk mendiskripsikan dan menganalisis :

1. Bentuk kemitraan PT Pelindo IV cabang Ambon dengan Pemerintah Kota Ambon dalam mendukung pelayanan jasa pelabuhan di pelabuhan Yos Sudarso Ambon.

2. Pelaksanaan kemitraan PT Pelindo IV cabang Ambon dengan Pemerintah Kota Ambon dalam mendukung pelayanan jasa pelabuhan di pelabuhan Yos Sudarso Ambon.

3. Faktor-faktor yang mendukung dan menghambat proses kemitraaan antara PT Pelindo IV cabang Ambon dengan Pemerintah Kota Ambon dalam mendukung pelayanan jasa pelabuhan di pelabuhan Yos Sudarso Ambon.

Berdasarkan tujuan penelitian yang telah disebutkan diatas, maka diharapkan hasil penelitian ini dapat memberikan manfaat sebagai berikut :

1. Secara teoritis, diharapkan dapat memberikan kontribusi bagi ilmu pengetahuan khususnya ilmu administrasi publik yang berkaitan dengan masalah pelaksanaan atau bentuk kemitraan.

2. Secara praktis, hasil penelitian ini diharapkan dapat memberikan sumbangan pemikiran kepada peneliti selanjutnya terkait kemitraan pada PT Pelindo IV cabang Ambon.

Agar tujuan penelitian dalam penelitian ini bisa tercapai, maka peneliti menggunakan teori kemitraan dan teori good governance untuk menjawab bentuk kemitraan kemitraan PT Pelindo IV cabang Ambon dengan Pemerintah Kota Ambon dalam mendukung pelayanan jasa pelabuhan di pelabuhan Yos Sudarso Ambon.

Sementara untuk menjawab pelaksanaan kemitraan PT Pelindo IV cabang Ambon dengan Pemerintah Kota Ambon dalam mendukung pelayanan jasa pelabuhan di 
pelabuhan Yos Sudarso Ambon peneliti menggunakan teori good governance dan teori risiko.

Adapun untuk menemukan faktor pendukung dan faktor penghambat kemitraan PT Pelindo IV cabang Ambon dengan Pemerintah Kota Ambon dalam mendukung pelayanan jasa pelabuhan di pelabuhan Yos Sudarso Ambon peneliti menggunakan teori analisis SWOT

\section{METODE PENELITIAN}

Jenis penelitian dalam penelitian ini menggunakan pendekatan kualitatif berlandaskan pada filsafat postpositivisme karena peneliti bermaksud memperoleh gambaran yang mendalam tentang pelaksanaan Kemitraan Sektor Pelabuhan.

Fokus dalam ini adalah untuk mendeskripsikan dan menganalisis bentuk, pelaksanaan serta faktor yang mendukung dang menghambat kemitraan antara PT Pelindo IV cabang Ambon dengan Pemerintah Kota Ambon dalam mendukung pelayanan jasa pelabuhan di pelabuhan Yos Sudarso Ambon.

Lokasi penelitian dalam penelitian ini adalah di PT Pelindo IV cabang Ambon. Alasan pemilihan lokasi tersebut karena PT Pelindo IV cabang Ambon sedang melakukan upaya perluasan lapangan penumpukan peti kemas bekerjasama dengan Pemerintah Kota Ambon.

Dalam penelitian ini sumber data diperoleh dari Informan dan peristiwa. Sedangkan metode pengumpulan data dalam penelitian ini dilakukan dengan wawancara, observasi, focus group discussion dan dokumentasi.

Teknik analisis data yang digunakan dalam penelitian ini terdiri atas beberapa komponen yaitu pengumpulan data, reduksi data, penyajian data, dan penarikan kesimpulan [3].

Keabsahan hasil temuan penelitian kualitatif merujuk pada yang disampaikan Moleong dimana keabsahan data dalam penelitian ini mengacu pada kriteria sebagai berikut : Kredibilitas, Keteralihan , Ketergantungan, Kepastian [4].

\section{HASIL DAN PEMBAHASAN}

a. Bentuk Kemitraan Antara PT. Pelindo IV cabang Ambon Dengan Pemerintah Kota Ambon Dalam Mendukung Jasa Pelayanan Di Pelabuhan.

Peneliti menganalisis sebagaimana menurut Rosen dalam Keban mengenai pengaturan Kerjasama. bahwa bentuk kerjasama yang dibangun antara PT Pelindo IV cabang Ambon dengan Pemerintah Kota Ambon memiliki kecenderungan pada model kerjasama Consortia yaitu pengaturan kerjasama dalam sharing sumberdaya, dimana Pihak PT Pelindo IV cabang Ambon memiliki sumber daya modal untuk melakukan perluasan lahan area lapangan penumpukan peti kemas. Sementara Pemerintah Kota Ambon memiliki sumberdaya aset lahan yang lokasinya berdekatan dengan pelabuhan Ambon yang bisa dimanfaatkan sebagai lapangan area penumpukan peti kemas.

Menurut Rosen dalam Keban kerjasama consortia telah dikenal sebagai cara yang jitu untuk mengambil manfaat dari ekonomi skala (economies of scales) [5].

1. Kemitraan dengan prinsip sharing sumberdaya antara PT Pelindo IV cabang Ambon dengan Pemerintah Kota Ambon lebih efektif dan efisien dalam menekan biaya Overhead pengerjaan proyek perluasan area lapangan penumpukan peti kemas.

2. Bentuk kerjasama consortia yang dimitrakan PT Pelindo IV cabang Ambon dengan Pemerintah Kota Ambon merupakan bentuk sharing investasi yang akan menguntungkan kedua belah pihak jika dibandingkan dengan perencanaan, pembangunan, pengoperasian dan pemeliharaan lapangan penumpukan peti kemas dilakukan sendirisendiri.

3. Dengan prinsip sharing sumberdaya akan meningkatkan kualitas pelayanan jasa pelabuhan yang diberikan PT Pelindo IV cabang Ambon karena sulitnya mendapatkan area perluasan lapangan penumpukan peti kemas mengingat kondisi kota Ambon yang berbukit sehingga dapat diantisipasi dengan pemanfaatan lahan pasar Nusaniwe milik Pemerintah Kota Ambon yang lokasinya berdekatan dengan pelabuhan Yos Sudarso.

4. Melalui sharing sumberdaya, PT Pelindo IV Cabang Ambon dengan Pemerintah Kota Ambon dapat bersama-sama mewujudkan kesejahteraan masyarakat Kota Ambon melalui pelayanan jasa kepelabuhan.

Menurut Mahmudi Kualitas layanan jasa pelabuhan yang diberikan PT Pelindo IV cabang Ambon kepada perusahaan pelayaran dapat diukur dengan standar pelayanan publik yang baik. Adapun mengenai cakupan standar 
pelayanan publik yang baik meliputi 6 (enam) standar, yaitu [6]:

1) Prosedur pelayanan : Secara garis besar terkait standar prosedur pelayanan jasa pelabuhan sudah baik karena prosedur layanan ini telah dibakukan dalam bentuk perjanjian kerjasama antara PT Pelindo IV cabang Ambon dengan perusahaan pelayaran yang menggunakan jasa layanan pelabuhan.

2) Waktu penyelesaian : Tahapan singkat dalam pengurusan izin tentu saja akan membuat waktu layanan yang dibutuhkan cepat. Dalam satu tahapan hanya memakan waktu 2 jam hingga 1 hari.

3) Biaya pelayanan :. Total biaya handling peti kemas dengan menggunakan jasa crane kapal sebesar Rp 896.000. Sedangkan total biaya handling petikemas dengan menggunakan LLC sebesar Rp 885.000. Biaya yang ditetapkan oleh PT Pelindo IV cabang Ambon ini sudah sesuai standar biaya jasa pelabuhan nasional.

4) Produk pelayanan : Produk layanan yang diberikan PT Pelindo IV cabang Ambon kepada pengguna jasa pelabuhan telah dijalankan sesuai dengan pedoman tentang sistem dan prosedur pelayanan. Namun yang masih menjadi kendala adalah keterbatasan area peti kemas yang dimiliki PT Pelindo IV cabang Ambon berdampak pada lambatnya pada aktifitas bongkar muat barang.

5) Sarana prasarana : Secara umum, peralatan yang mendukung bongkar muat peti kemas perlu diperbarui karena banyak yang sudah berusia di atas 20 tahun. Sementara kebutuhan lapangan penumpukan peti kemas berdasarkan penelitian Amos Panggua total kekurangan Container Yard/lapangan penumpukan barang minimal yang dibutuhkan untuk mengantisipasi jumlah petikemas yang akan masuk pada tahun 2016 sekitar $48.000 \mathrm{~m}^{2}$ [7]. Sementara kapasitas container yard yang saat ini tersedia hanya seluas 23.549 $\mathrm{m}^{2}$. Berdasarkan data tersebut, dapat dievaluasi bahwa penyediaan sarana prasana ini masih terdapat kendala. Namun pihak PT Pelindo IV cabang Ambon sudah berusaha melakukan upaya untuk mengantisipasi hal tersebut dengan melakukan reklamasi pantai secara bertahap dan mengupayakan agar dapat segera memanfaatkan lahan milik pemkot sebagai area perluasan lapangan penumpukan peti kemas. Hal lain yang perlu dibenahi yaitu, masih kurangnya tingkat keamanaan area lapangan penumpukan peti kemas dan belum adanya sistem drainase yang baik untuk mengindari banjir yang akan menggenangi area lapangan peti kemas.

6) Kompetensi petugas pemberi pelayanan : Peningkatan kompetensi petugas pemberi pelayanan pada PT Pelindo IV cabang Ambon dilakukan dengan cara melakukan evaluasi kinerja secara berkala. Dari evaluasi kinerja ini, nantinya akan dipetakan alternatif pemecahan masalah yang ditemukan misalnya dengan mengadakan upgrading tentang standart pelayanan kerja, pemberian motivasi dan rewarding pada karyawan dan perombakan struktur organisasi.

Dari hasil analisis peneliti di atas, didapatkan sebuah analisa bahwasannya secara umum pelayanan jasa pelabuhan yang diberikan PT Pelindo IV cabang Ambon sudah memenuhi standar pelayanan yang baik. Namun yang masih menjadi permasalahan adalah dalam masalah sarana dan prasarana dimana perlunya peremajaan alat yang mendukung kelancaran arus bongkar muat dan perluasan area lapangan penumpukan peti kemas.

\section{b. Pelaksanaan Kemitraan Antara PT Pelindo IV cabang Ambon Dengan Pemerintah Kota Ambon Dalam Mendukung Jasa Pelayanan Di Pelabuhan.}

Pihak-pihak yang terlibat dalam kemitraan antara PT Pelindo IV cabang Ambon dengan Pemerintah Kota Ambon adalah sebagai berikut:

Dalam kemitraan ini, PT Pelindo IV cabang Ambon dan Pemerintah Kota Ambon merupakan pihak yang mewakili sektor publik dimana PT Pelindo IV cabang Ambon sebagai perusahaan Badan Usaha Milik Negara yang memberikan jasa pelayanan pelabuhan kepada masyarakat yang ingin meningkatkan kualitas layanannya dengan melakukan perluasan area lapangan penumpukan peti kemas. Pemerintah Kota Ambon sebagai wakil negara yang juga bertugas meningkatkan kesejahteraan rakyat melalui pelayanan publik mendukung adanya upaya perluasan lapangan penumpukan peti kemas milik PT Pelindo IV cabang Ambon melalui penyediaan sumber daya aset berupa lahan pasar 
Nusaniwe yang akan dijadikan sebagai lokasi perluasan lapangan penumpukan peti kemas.

Sektor swasta dalam kemitraan yang dibangun antara Pemerintah Kota Ambon dengan PT Pelindo IV cabang Ambon adalah perusahaan pelayaran pengguna jasa pelayanan pelabuhan seperti PT Meratus Line cabang Ambon, PT Tempuran Mas cabang Ambon dan PT Tanto Intim Line cabang Ambon. Perusahaan pelayaran berperan memberikan jasa ekspedisi laut guna memperlancar distribusi barang kepada masyarakat kota Ambon yang tentunya distribusi barang ini akan menunjang aktifitas perekonomian masyarakat kota Ambon dan mendukung petumbuhan ekonomi.

Adanya kemitraan yang dibangun antara Pemerintah Kota Ambon dengan PT Pelindo IV cabang Ambon merupakan upaya mencukupi kebutuhan masyarakat akan barang yang didistribusikan melalui transpotasi laut. Jadi peran masyarakat Ambon dalam kemitraan ini adalah sebagai konsumen.

Kebijakan yang diambil PT Pelindo IV cabang Ambon dengan memanfaatkan lahan pasar Nusaniwe yang merupakan aset Pemerintah Kota Ambon dimaksudkan untuk peningkatan jasa pelayanan pelabuhan khususnya dalam mendukung kelancaran arus bongkar muat barang. Namun hingga saat ini proses pembebasan lahan pasar Nusaniwe masih belum bisa dilakukan.

Menurut Budiati, kemitraan antara PT Pelindo IV cabang Ambon dengan Pemerintah Kota Ambon jika dianalisis dengan menggunakan prinsip-prinsip good governance dapat diuraikan sebagai berikut :

1. Partisipasi Masyarakat

Tim kajian yang dibentuk Pemerintah Kota Ambon dalam upaya pemanfaatan lahan pasar Nusaniwe dan rencana relokasi para pedagang pasar tidak melibatkan peran serta masyarakat. Terbukti tidak adanya sosialisasi secara resmi dari Pemerintah Kota Ambon terkait rencana pemanfaatan lahan pasar Nusaniwe sebagai area perluasan lapangan penumpukan peti kemas.

2. Tegaknya Supremasi Hukum

Pemanfaatan lahan pasar Nusaniwe sebagai area perluasan lapangan penumpukan peti kemas masih menunggu disekapatinya MoU. sehingga relokasi pedagang pasar Nusaniwe oleh Pemerintah Kota Ambon belum bisa dilakukan karena belum ada dasar hukumnya.
3. Transparansi

Terbengkalainya upaya pembebasan lahan pasar Nusaniwe menunjukkan kurangnya koordinasi dan sinkronisasi antara PT Pelindo IV cabang Ambon dengan Pemerintah Kota Ambon. Sementara penyebab kurangnya koordinasi dan sinkronisasi itu sendiri belum bisa diidentifikasi. Masih sulitnya masyarakat Kota Ambon dalam mengakses arus informasi terkait penyebab permasalahan ini menunjukkan tidak adanya transparansi dari Pemerintah Kota Ambon.

4. Peduli pada Stakeholder

Kurangnya koordinasi antar pihak dalam kemitraan antara Pemerintah Kota Ambon dengan PT Pelindo IV cabang Ambon menunjukkan rendahnya kepedulian antar pihak dalam upaya pembebasan lahan pasar Nusaniwe.

5. Berorientasi pada Konsensus

Belum adanya kesepakatan terkait pemanfaatan lahan pasar Nusaniwe menunjukkan bahwa masih adanya perbedaan perspektif dalam pemanfaatan lahan pasar Nusaniwe. Bisa jadi perbedaan perspektif ini berkaitan dengan pembagian peran dalam proyek, rencana pengelolaan ataupun pembagian keuntungan.

6. Kesetaraan

Belum adanya MoU yang disepakati menunjukkan bahwa pihak-pihak yang terlibat dalam kemitraan belum mendapatkan hak yang setara dalam pembagian keuntungan dan pemenuhan kepentingan setiap pihak.

7. Efektivitas dan Efisiensi

Masih terbengkalainya upaya pemanfatan lahan pasar Nusaniwe sebagai area perluasan lapangan penumpukan peti kemas menjadikan kemitraan antara PT Pelindo IV cabang Ambon dengan Pemerintah Kota Ambon belum efektif dalam melayani kebutuhan masyarakat akan kebutuhan jasa pelayanan pelabuhan. Pembebasan lahan pasar Nusaniwe yang masih belum bisa dilakukan menunjukkan bahwa pemanfaatan sumber daya lahan yang dimiliki Pemerintah Kota Ambon belum efisien.

8. Akuntabilitas

Pelaksanaan kemitraan antara Pemerintah Kota Ambon dengan PT Pelindo IV cabang Ambon belum bisa dipertanggungjawabkan karena semua stake holder belum bisa 
merasakan dampak dari kemitraan ini.

9. Visi strategis

Perluasan area lapangan penumpukan peti kemas merupakan visi strategis dalam mengantisipasi terus meningkatnya arus bongkar muat barang di pelabuhan Yos Sudarso. Namun masih terhambatnya proses pembebasan lahan pasar Nusaniwe menjadikan visi strategis ini belum tercapai pada tataran aplikatif.

Dari analisis di atas dapat dipahami bahwa kemitraan antara PT Pelindo IV cabang Ambon dengan Pemerintah Kota Ambon belum sesuai dengan prinsip-prinsip good governance. Hal ini terlihat dalam kemitraan yang dibangun antara Pemerintah Kota Ambon dengan PT Pelindo IV cabang Ambon yang masih mencerminkan hubungan yang kurang harmonis dengan stake holder yang terkait dalam kemitraan. Pemerintah Kota Ambon kurang bisa membangun komunikasi dengan PT Pelindo IV cabang Ambon sehingga koordinasi dalam melakukan pembebasan lahan pasar Nusaniwe menjadi terhambat.

Dengan mengacu pada pendapat Rosen dalam Keban bahwa belum disepakatinya MoU secara legal formal antara PT Pelindo IV cabang Ambon dengan Pemerintah Kota Ambon bukan berarti tidak adanya kemitraan antara PT Pelindo IV cabang Ambon dengan Pemerintah Kota Ambon karena sejak tahun 2011 koordinasi antara kedua belah pihak sudah dilakukan sehingga secara handshake agreement kemitraan sudah dilakukan. Hasil dari koordinasi tersebut berupa lay out bahwa rencana pembangunan pelabuhan Ambon yang memanfaatkan lahan pasar Nusaniwe sebagai area perluasan lapangan penumpukan peti kemas akan diprioritaskan pembangunannya dapat terealisasi pada tahun 2013 meskipun dalam kenyataannya hingga tahun 2014 ini belum bisa terealisasi.

Sebagai akibat masih terhambatnya realisasi pemanfaatan lahan pasar Nusaniwe tersebut maka menurut Kerzner, Smith dan Walter dalam Grimsey terdapat risiko sebagai berikut [7]:

1. Risiko pengoperasian :

Terhambatnya proses kemitraan berakibat pada terganggunya pelayanan jasa bongkar muat barang di pelabuhan karena terjadi penumpukan peti kemas yang melebihi kapasitas lapangan penumpukan peti kemas.
2. Risiko pendapatan :

a. Sesuai dengan dokumen perjanjian antara PT Pelindo IV cabang Ambon dengan perusahaan pelayaran pengguna jasa pelayanan pelabuhan. Terlambatnya bongkar muat barang karena keterbatasan lapangan penumpukan peti kemas berakibat pada denda yang harus dibayar PT Pelindo IV cabang Ambon kepada perusahaan pelayaran yaitu denda $5 \%$ dari imbalan jasa pelayanan pelabuhan yang ditetapkan PT Pelindo IV cabang Ambon jika keterlambatan bongkar muat barang hingga sebulan dan denda $10 \%$ dari imbalan jasa pelabuhan yang ditetapkan PT Pelindo IV cabang Ambon jika keterlambatan bongkar muat barang hingga 2 (dua) bulan atau lebih.

b. Proses bongkar muat barang di pelabuhan yang tersendat kemungkinan akan berakibat pada menurunnya kualitas barang atau bahkan kerusakan barang karena terlalu lama dalam peti kemas. Hal ini membuat perusahaan pelayaran harus menanggung kerugian.

3. Risiko kepercayaan :

a. Masih belum terealisasinya proyek perluasan lapangan penumpukan peti kemas milik PT Pelindo IV cabang Ambon karena pengkajian yang belum selesai dapat menurunkan kepercayaan PT Pelindo IV cabang Ambon terhadap Pemerintah Kota Ambon yang berakibat pembatalan kemitraan secara sepihak.

b. Terhambatnya proses bongkar muat peti kemas di pelabuhan menyebabkan penurunan kualitas pelayanan yang diberikan perusahaan pelayaran kepada perusahaan pengguna jasa ekspedisi. Hal ini tentu akan menurunkan kepercayaan publik yang berisiko menurunnya jumlah pengguna jasa.

4. Risiko Teknis

Kemitraan yang masih belum ada kejelasan secara legal formal karena terganjal proses pengkajian MoU yang belum selesai membuat Pemerintah Kota Ambon kesulitan dalam sosialisasi upaya relokasi para pedagang pasar Nusaniwe.

5. Risiko keuangan

Keterlambatan dalam bongkar muat peti kemas berdampak pada keterlambatan perusahaan pengguna jasa pelayaran terlambat mendapatkan barangnya sehingga hal ini akan membuat 
tersendatnya distribusi barang di pasaran yang menyebabkan harga barang di kota Ambon mengalami kenaikan karena persediaan barang terbatas.

6. Risiko keamanan

Kemudahan akses bagi masyarakat untuk masuk ke lapangan penumpukan peti kemas karena terbatasnya lahan membuat tata letak peti kemas kurang terjamin keamanannya yang memungkinkan terjadinya tindak pidana pencurian barang dalam peti kemas.

Dari paparan risiko di atas, peneliti menganalisis bahwa banyaknya kendala yang membuat terhambatnya proses pemanfaatan lahan pasar Nusaniwe sebagai area perluasan lapangan penumpukan peti kemas milik PT Pelindo IV cabang Ambon berdampak munculnya berbagai risiko. Baik risiko pengoperasian, risiko keuangan, risiko teknis, risiko kepercayaan, risiko pendapatan maupun risiko keamanan.

\section{c. Faktor-Faktor Pendukung Dan Penghambat Proses Kemitraan Antara PT Pelindo IV cabang Ambon dengan Pemerintah Kota Ambon. \\ Dari hasil penelitian yang peneliti} jabarkan sebelumnya, dapat diidentifikasi bahwa yang menjadi faktor pendukung dalam kemitraan antara PT Pelindo IV cabang Ambon dengan Pemerintah Kota Ambon adalah sebagai berikut :

1. Meningkatnya arus bongkar muat barang di pelabuhan Yos Sudarso Ambon dari tahun ke tahun menunjukkan bahwa proses distribusi barang melalui jalur laut semakin dinikmati karena prosesnya dianggap lebih cepat, murah dan dan risikonya bisa diminimalisir dibandingkan melalui jalur udara.

2. Ketersediaan lahan milik Pemerintah Kota Ambon yang akan dijadikan sebagai area perluasan lapangan penumpukan peti kemas.

Apabila dianalisa mengunakan teori analisis SWOT maka dapat dijabarkan dalam penjelasan berikut [8]:

1. Kekuatan

a. Ketersediaan sumber daya lahan milik Pemerintah Kota Ambon.

b. Ketersediaan sumber daya modal yang dimiliki PT Pelindo IV cabang Ambon.

2. kelemahan

a. Masih belum selesainya proses pengkajian terhadap rencana relokasi pedagang pasar Nusaniwe yang mendiami lahan Pemerintah Kota Ambon. b. Masih belum selesainya pembuatan MoU sebagai akibat dari belum selesainya pengkajian.

c. Tidak adanya sosialisasi secara resmi dari Pemerintah Kota Ambon terkait rencana relokasi pedagang pasar Nusaniwe.

d. Kurangnya koordinasi dan sinkronisasi antara PT Pelindo IV cabang Ambon dengan Pemerintah Kota Ambon.

3. Peluang

a. Arus bongkar muat barang yang dari tahun ke tahun mengalami peningkatan yang berdampak pada semakin meningkatnya kebutuhan lapangan penumpukan peti kemas.

b. Pertumbuhan ekonomi kota Ambon yang mengalami peningkatan yang dipengaruhi pelayanan jasa bongkar muat barang di pelabuhan.

4. Ancaman

Proses pengkajian yang lama terhadap lahan yang akan digunakan sebagai area perluasan lapangan penumpukan peti kemas bisa berdampak pada pembatalan sepihak kemitraan.

Dari pemetaan kekuatan, kelemahan, kesempatan dan ancaman, tentang matriks SWOT dapat dibuat strategi tindakannya sebagai berikut.

1. Keterbatasan lapangan penumpukan peti kemas yang dimiliki PT Pelindo IV cabang Ambon jika tidak segera ditanggulangi dapat menyebabkan penumpukan peti kemas di pelabuhan Yos Sudarso yang berakibat pada terhambatnya arus bongkar muat barang. Oleh karena itu, untuk mengantisipasi hal tersebut, alternatif solusinya dengan upaya reklamasi pantai sebelum pemanfaatan lahan pasar Nusaniwe bisa dibebaskan.

2. Kurangnya koordinasi dan sinkronisasi antara PT Pelindo IV cabang Ambon dengan Pemerintah kota Ambon dalam pemanfaatan lahan pasar Nusaniwe sebagai area perluasan lapangan penumpukan peti kemas dapat berisiko adanya pembatalan dalam kemitraan. Oleh karena itu, permasalahan tersebut harus segera diselesaikan dengan cara mencari akar permasalahannya. Kesadaran untuk segera berkoordinasi dan sinkronisasi antar stake holder terkait sangat dibutuhkan. Dengan begitu, proses pengkajian bisa segera mencapai titik final dan MoU bisa disepakati. 
Bila dikaitkan dengan sumber error yang dikemukakan oleh Makie dan Preston dalam Grimsey bahwa dalam proyek trasportasi ditemukan 4 (empat) dari 21 (dua puluh satu) sumber error yang menghambat proses kemitraan antara PT Pelindo IV cabang Ambon dengan Pemerintah Kota Ambon, diantaranya [9]:

1. Kesulitan mengevaluasi dampak lingkungan yaitu proses sosialisasi dari Pemerintah Kota Ambon yang belum jelas secara resmi membuat relokasi pedagang pasar Nusaniwe belum bisa dilaksanakan.

2. Mengabaikan risiko karena periode persiapan proyek yang lama Kurangnya koordinasi dan sinkronisasi antara Pemerintah Kota Ambon dengan PT Pelindo IV cabang Ambon sehingga pelaksanaan kemitraan secara formal menjadi terhambat.

3. Mengabaikan masalah di awal proyek yaitu masih diberlakukannya retribusi karcis kepada para pedagang pasar Nusaniwe adalah wujud pengakuan keberadaan pasar Nusaniwe oleh Pemerintah Kota Ambon sehingga membuat rencana relokasi para pedagang pasar semakin tidak jelas.

4. Ketidakmampuan (atau keengganan) untuk memperoleh data yang baik dan realistis yaitu terlalu lamanya proses pengkajian MoU menandakan keengganan untuk memperoleh data yang baik dan realistis.

\section{KESIMPULAN}

1. Bentuk kemitraan yang dibangun antara PT Pelindo IV cabang Ambon dengan Pemerintah Kota Ambon memiliki kecenderungan ke bentuk kerjasama Consortia. Sementara bentuk jasa pelayanan kapal, jasa pelayanan barang dan jasa pelayanan terminal peti kemas sudah sesuai prosedur namun harus ditingkatkan kecepatannya dengan memperluas lapangan penumpukan peti kemas sehingga kemitraan antara PT Pelindo IV cabang Ambon dengan Pemerintah Kota Ambon harus segera dilakukan.

2. Pihak-pihak yang terlibat dalam kemitraan antara PT Pelindo IV cabang Ambon dengan Pemerintah Kota Ambon adalah sebagai berikut sektor publik diwakili oleh Pemerintah Kota Ambon dan PT Pelindo, sektor privat diwakili oleh perusahaan pelayaran (PT Tanto Intim Line, PT Tempuran Emas dan PT Meratus Line) sedangkan pihak masyarakat diwakili oleh masyarakat kota Ambon. sementara Proses pelaksanaan kemitraan antara PT Pelindo IV cabang Ambon dengan Pemerintah Kota Ambon secara legal formal masih menunggu dibuatnya MoU. Namun secara handshake agreement kemitraan ini sudah dilaksanakan sejak tahun 2011. Pengkajian MoU yang lama mencerminkan tata kelola pemerintahan yang dilaksanakan di lingkungan Pemerintah Kota Ambon belum sesuai dengan prinsip-prinsip good governance. Sehingga terdapat risiko keuangan, risiko pendapatan, risiko kepercayaan, risiko keamanan dan risiko teknis sebagai akibat kemitraan antara PT Pelindo IV cabang Ambon dengan Pemerintah Kota Ambon.

3. Faktor pendukung : 1) Meningkatnya arus bongkar muat barang di pelabuhan Yos Sudarso Ambon dari tahun ke tahun yang membutuhkan ketersediaan lapangan penumpukan peti kemas yang memadai. 2) Ketersediaan lahan milik Pemerintah Kota Ambon yang akan dijadikan sebagai area perluasan lapangan penumpukan peti kemas. Sementaran faktor penghambatnya : 1) Masih belum selesainya proses pengkajian terhadap rencana relokasi pasar Nusaniwe, 2) Belum adanya sosialisasi secara resmi dari Pemerintah Kota Ambon terkait relokasi pedagang pasar Nusaniwe, 3) Masih diberlakukannya retribusi karcis di pasar Nusaniwe, 4) Kurangnya koordinasi dan sinkronisasi antara Pemerintah Kota Ambon dengan PT Pelindo IV cabang Ambon sehingga rencana kemitraan ini menjadi terhambat.

\section{UCAPAN TERIMA KASIH}

Dengan memanjatkan puji syukur kehadirat Allah SWT, atas limpahan Rahmat serta Hidayah-NYA peneliti dapat menyelesaikan karya ilmiah ini sebagai salah satu syarat memperoleh gelar Magister Administrasi Publik dari Program Pascasarjana Magister Administrasi Publik Fakultas Ilmu Administrasi Universitas Brawijaya Malang.

Ucapan terima kasih penulis sampaikan kepada para dosen pembimbing, Prof.Dr.Sumartono,MS dan Dr.Hermawan, S.Ip, M.Si yang telah memberikan arahan, masukan dan motivasi sehingga jurnal ini bisa selesai dan terpublikasi. 
Ucapan terima kasih juga penulis sampaikan kepada pihak PT Pelindo IV cabang Ambon yang telah berkontribusi memberikan data dan informasi yang mendukung kelancaran pembuatan jurnal ini.

Tidak lupa ucapan terima kasih juga penulis sampaikan kepada segenap civitas akademika Universitas Darussalam Kota Ambon yang telah memberikan dukungan dan motivasi hingga jurnal ini bisa terselesaikan.

Terakhir, ucapan terima kasih penulis sampaikan kepada kedua orangtua, papa Junanta Derlen dan mama Erly Derlen yang tidak hentihentinya mendoakan kelancaran studi penulis serta memberikan dukungan baik moril maupun materiil.

\section{DAFTAR PUSTAKA}

[1]. Budiati, Lilian. 2012. Good Governance dalam Pengelolaan Lingkungan Hidup. Ghalia Indonesia. Bogor.

[2].Weydan, Hussien. 2009. Public - Private Partnerships Lessons Learned From A Partnership Consolidated Contractors Company And The Morganti Group Inc. AlBalqa' Applied University Al-Huson University College And The Usaid Jordan Economic Development Program. United States Agency for International Development. USA. http ://pdf.usaid.gov/pdf_docs/PNADT050.pdf diakses 23 juli 2014.

[3].Denzin, Norman.K \& Yvonna S. Lincoln. 2009. Handbook Of Qualitative Research. Diterjemahkan oleh Dariyanto dkk. Pustaka Pelajar. Yogyakarta

[4].Moleong, Lexxy J. 2006. Metode Penelitian Kualitatif. Rosdakarya. Bandung.

[5].Keban, Y.T. 2004. Enam Dimensi Strategis Administrasi Publik: Konsep, Teori dan Isu. Gava Media. Yogyakarta.

[6].Mahmudi. 2010. Manajemen Kinerja Sektor Publik. UPP STIM YKPN. Yogyakarta.

[7].Panggua, Amos. 2011. Makalah "Kapasitas Lapangan Penumpukan Pelabuhan Ambon Dengan Sistem Lupsum". Ambon.

[8]. David, Fred R. 2006. Managemen strategi. Buku 1 Edisi 10. Salemba Empat. Jakarta.

[9].Grimsey, Darrin \& Mervyn K. Lewis. 2004. Public Private Partnership : The Worldwide Revolution In Infrastructure Provision And Project Finance. Edward Elgar Publishing. USA. 